\title{
STATINS USE AND RISK OF SARCOPENIA IN COMMUNITY DWELLING OLDER ADULTS
}

\author{
ANNA MARIE HERGHELEGIU ${ }^{1,2}$, GABRIEL IOAN PRADA ${ }^{1,2}$, RALUCA MIHAELA NACU ${ }^{2}$, \\ ANDREI KOZMA $^{3 *}$, IOANA DANA ALEXA ${ }^{4}$ \\ ${ }^{I}$ National Institute of Geriatrics and Gerontology "Ana Aslan”, 9 Căldărușani St., Sector 1, Bucharest, Romania \\ ${ }^{2}$ University of Medicine and Pharmacy "Carol Davila”, 37 Dionisie Lupu St., Sector 2, Bucharest, Romania \\ Tel.: $0.21318 .0719 /$ Fax.: 0.213180730 \\ 3 "Fr. I. Rainer" Anthropology Institute of Romanian Academy, Bucharest, Romania \\ ${ }^{4}$ University of Medicine and Pharmacy "Gr.T.Popa”, 16 Universității St., Iasi, Romania
}

*corresponding author: correspondence.nigg@gmail.com

\begin{abstract}
Current guidelines recommend statin use for cardiovascular risk management in adults as well as older people but in many situations these recommendations feature individualized drug management decisions. Statin induced myalgia and muscular toxicity syndrome are gaining more and more attention especially in older patients with sarcopenia. In this case-control study we investigated the association between long term statin use and risk of sarcopenia. A total number of 368 patients with a mean age of 76.43 met the eligibility criteria and were included in the study. Statin treatment significantly increased the odds of patients' being at high risk for sarcopenia by a factor of $2.62(\mathrm{OR}=2.62,95 \% \mathrm{CI}: 1.53-4.46 ; \mathrm{p}<0.001)$. The enhanced risk of sarcopenia was associated with lipophilic statins use and positively correlated with the dosage. When correlating the education level, area of residence, income and living arrangements, statin administration remained significantly associated with a high risk for sarcopenia.
\end{abstract}

\section{Rezumat}

Ghidurile clinice actuale recomandă folosirea statinelor pentru managementul riscului cardiovascular atât la adulți, precum și la persoanele în vârstă, dar în multe situaţii recomandările specifică decizii terapeutice individualizate. Mialgia şi sindromul de toxicitate musculară induse de statine câștigă din ce în ce mai multă atenție, în special la pacienții vârstnici cu sarcopenie. În acest studiu caz-martor a fost investigată asocierea dintre utilizarea statinelor pe termen lung şi riscul de sarcopenie la vârstnici. În studiu au fost incluşi un număr total de 368 pacienți cu vârsta medie de 76,43 ani care au îndeplinit criteriile de eligibilitate. Tratamentul de lungă durată cu statine a crescut semnificativ cotele de risc pentru sarcopenie cu un factor de 2,62 (OR = 2,62, IC 95\%: 1,53 - 4,46, p < 0,001). Riscul crescut de sarcopenie a fost asociat cu utilizarea statinelor lipofile și a fost corelat pozitiv cu doza administrată. Asocierea dintre administrarea de statine şi riscul crescut de sarcopenie s-a menţinut semnificativă şi atunci când factori precum nivelul de educaţie, venitul, precum şi mediul de viaţă au fost luate în considerare.

Keywords: statin, sarcopenia, falls, older adults

\section{Introduction}

Sarcopenia is considered a geriatric syndrome characterized by a progressive decline in skeletal muscle mass, muscle strength and performance $[1,2]$. It is thought to affect approximately 10 percent of people aged $60-70$ years and its prevalence increases with age reaching up to 50 percent in people over 80 years [3, 4]. A global consensus on the use of the term sarcopenia and its clinical outcomes has not yet been reached although there is evidence that the decline in the overall performance of skeletal muscle contributes to the loss of independence and frailty and increases the risk of falls [2, 5-7]. The presence of sarcopenia has been associated with an increased risk of incident disability and mortality [8-10].
The impairment of skeletal muscle functioning in older age is determined not only by the decrement in muscle mass but by alterations in muscle composition and remodelling and by age related changes in the nervous system at multiple levels [1113]. The aetiology of sarcopenia is certainly multifactorial nonetheless suboptimal physical activity and poor nutritional intake are among the most cited associated modifiable risk factors [1416].

Statins are widely used drugs for cardiovascular risk management, often administered on long term basis [17-19]. Common side effects of statins are myalgia and exercise induced myalgia, muscle weakness and/or rhabdomyolysis with or without creatine kinase elevation [20-22]. The statin induced 
muscular toxicity syndrome is gaining more and more attention and is even more prevalent than previously thought, reaching up to $29 \%$, even though there is no recommended standardized evaluation method $[23,24]$. Statin induced myalgia represents a limiting factor for physical activity and thus potentially contributing to an increased risk for sarcopenia. Statins not only reduce the production of endogenous cholesterol, but of other products of the mevalonate pathway involved in structural protein formation and regulation, oxidative phosphorylation, cell growth, mitochondrial function and gene transcription but the molecular mechanisms of statin induced myopathy are not yet fully elucidated $[25,26]$. Statin toxicity also depends on factors involved in drug metabolism such as cytochrome P450s and CYP3A4 subfamily enzymes.

Studies on the association between statin use and muscle quality and function have generated contradictory results $[23,24,26]$. We hypothesized that statin administration could contribute to an enhanced risk of sarcopenia in older people. The aim of this study was to evaluate the relationship between statin use and the risk of sarcopenia. A secondary objective was to assess the association between the gait speed test and risk of falls in community dwelling older adults.

\section{Materials and Methods}

\section{Study design}

The present study was carried out at the National Institute of Gerontology and Geriatrics "Ana Aslan" between 2015 - 2016. All procedures and experimental protocols employed in this study were in compliance with the ethical principles stated in the World Medical Association Declaration of Helsinki. All participants included in this study have signed an informed consent to use their medical data for research purposes and without disclosure of personal identification information to third parties. The approval of the Ethics Committee of the National Institute of Gerontology and Geriatrics "Ana Aslan" was obtained before study commencement.

Subject's selection

Participants were recruited from patients referred to the National Institute of Gerontology and Geriatrics "Ana Aslan" for various chronic conditions by general practitioners or other specialists. All consecutive patients were assessed for compliance to the eligibility criteria. Subjects 65 years of age and older, who were independently living in their communities were evaluated for study inclusion. Patients with a high risk for sarcopenia were considered potential participants in the "case" group and were evaluated against exclusion criteria. As age and sex are among the most cited risk factors for sarcopenia $[14,27]$, to increase the power of test, each case was matched for age $( \pm 1$ year) and sex with three controls who were not at risk for sarcopenia. Exclusion criteria were: acute or subacute disorders as reasons for admittance, supported walking, medium and severe neurocognitive disorders, Parkinson's disease and syndromes, stable angina Canadian Cardiovascular Society grades III and IV, heart failure New York Heart Association (NYHA) III and IV, peripheral artery disease Fontaine class II, III and IV, treatment with sulfonylureas or glinides, body mass index $(\mathrm{BMI})<$ $18.5 \mathrm{~kg} / \mathrm{m}^{2}$ and $>30 \mathrm{Kg} / \mathrm{m}^{2}$. Patients who were receiving statin treatment were selected only if the statin administration had been continuous for at least one year prior to study initiation.

Variables definition and data collection

The European Working Group on Sarcopenia in Older People (EWGSOP) recommends the gait speed test to identify patients at risk of sarcopenia (a cut-off point of $<0.8 \mathrm{~m} / \mathrm{s}$ ) [28]. In our study the gait speed was measured over a distance of 4 meters while the patients were instructed to "walk at a comfortable or usual pace". The average speed was calculated for 3 walking repetitions [29, 30]. Risk of falls was assessed with the Hendrich II Fall Risk Model ${ }^{\mathrm{TM}}$. This falls risk assessment instrument has been validated in different health care settings and is considered one of the most reliable tools among its kind [31, 32]. It attributes risk points for each of the following factors: confusion, disorientation and/or impulsivity, symptomatic depression, altered elimination, dizziness or vertigo, male sex, administration of antiepileptics (or dosage changes or cessation), administration of benzodiazepines and poor performance in the "Get-Up-and-Go" test of rising from a seated position [33]. Scores of $>5$ identify a patient as high risk for falls [33]. Statin use (type, dosage and duration of administration) was documented from medical charts, history taking and by inspecting the medication bag at hospital admittance. The exclusion criteria and socio demographic characteristics were documented from patients' medical charts and medical history. The following socio demographic characteristics were recorded: age, sex, area of residence, income (lower or higher than the national average monthly pension) [34], living arrangements (alone or with a relative/friend) and level of formal education (primary school, high school and college or university).

Statistical analysis

The estimated sample size to detect an odds ratio (OR) of 2.00 or greater was 92 cases and 276 controls based on a two-sided alpha of 0.05 , a power of $80 \%$, and a $30 \%$ exposed proportion in the control group. Data features are depicted with 
descriptive statistics. Conditional logistic regression analyses were performed to ascertain the effects of statin use, type of statin, dose of statin, area of residence, living arrangements, income level and level of education on the likelihood that participants are at high risk of sarcopenia [34]. We reported odds ratios as a measure of effect size with a $95 \%$ confidence interval (CI). We reported the logistic regression Wald chi square test for independence for falls risk variable in cases and control groups. All p-values are two-sided and $\mathrm{p}<0.05$ was considered statistically significant. Statistical analyses were performed in SPSS.

\section{Results and Discussion}

A total number of 368 patients met the eligibility criteria and were included in the study. The mean age of study participants was 76.43 years and the majority of them were females $(62.77 \%)$. The relative number of persons living in urban areas was similar in both cases and control groups (Table I). Compared to controls, the group at high risk of sarcopenia was characterized by lower levels of education and lower income. Most of the study participants were living with a spouse/partner/family member although the percentage was higher in the control group (Table I).

Table I

Socio demographic characteristics of the study group

\begin{tabular}{|l|c|c|c|}
\hline \multicolumn{1}{|c|}{ Characteristics } & $\begin{array}{c}\text { Cases (N = 92) } \\
\text { Mean (SD)/\% }\end{array}$ & $\begin{array}{c}\text { Controls (N = 276) } \\
\text { Mean (SD)/\% }\end{array}$ & $\begin{array}{c}\text { Sample (N = 368) } \\
\text { Mean (SD)/\% }\end{array}$ \\
\hline Age & $76.62(4.74)$ & $76.37(4.58)$ & $76.43(4.6)$ \\
\hline Female & \multicolumn{3}{|c|}{62.77} \\
\hline Living in rural area & 25 & 21 & 22 \\
\hline Living alone & 20.65 & 14.85 & 16.3 \\
\hline 4 - 8 years of formal education & 27.2 & 14.9 & 17.9 \\
\hline 9 - 12 years of formal education & 54.3 & 39.9 & 43.5 \\
\hline >12 years of formal education & 18.5 & 45.3 & 38.6 \\
\hline Low income* & 28.3 & 14.1 & 17.7 \\
\hline
\end{tabular}

$\mathrm{SD}=$ standard deviation; * low income $=$ under the medium pension/month expressed in local currency RON: in 2015 was 892 RON, in 2016948 RON [35].

The mean gait speed in the entire study sample was $0.94 \pm 0.22 \mathrm{~m} / \mathrm{s}$ with a minimum of $0.5 \mathrm{~m} / \mathrm{s}$ and a maximum of $1.38 \mathrm{~m} / \mathrm{s}$. In the overall sample $46.7 \%$ of the patients were taking statins, mostly atorvastatinum, while the proportion in cases group was almost twice as that in the controls. The proportion of subjects treated with simvastatinum was slightly higher in the control group compared to cases (Table II). According to their individual cardiovascular risk, most patients required a moderate intensity statin treatment [17] while $10.9 \%$ of cases received a high drug dose [17] as compared to only $1.4 \%$ in controls. Approximately one in five patients at high risk for sarcopenia were also considered to have a high risk for falls (Table II). Indeed, the association between high risk for sarcopenia and high risk for falls was statistically significant (Wald $\chi^{2}=5.48 ; \mathrm{p}=0.03$ ).

Table II

Gait speed, risk of falls and statin use in study group of patients

\begin{tabular}{|c|c|c|c|}
\hline Characteristic & $\begin{array}{l}\text { Cases }(\mathrm{N}=92) \\
\text { Mean }(\mathrm{SD}) / \%\end{array}$ & $\begin{array}{c}\text { Controls }(\mathrm{N}=276) \\
\text { Mean }(\mathrm{SD}) / \% \\
\end{array}$ & $\begin{array}{c}\text { Sample }(\mathrm{N}=368) \\
\text { Mean }(\mathrm{SD} ; \min -\max ) / \%\end{array}$ \\
\hline Gait speed $(\mathrm{m} / \mathrm{s})$ & $0.67(0.085)$ & $1.08(0.16)$ & $0.94(.22 ; 0.5-1.38)$ \\
\hline Risk of falls & 23.9 & 15.2 & 17.4 \\
\hline Statin use & 62 & 41.7 & 46.7 \\
\hline atorvastatinum & 39.1 & 22.5 & 26.6 \\
\hline simvastatinum & 8.7 & 10.9 & 10.3 \\
\hline rosuvastatinum & 14.1 & 8.3 & 9.8 \\
\hline \multicolumn{4}{|l|}{ Statin dosage* } \\
\hline moderate doses & 51.1 & 40.2 & 42.9 \\
\hline high doses & 10.9 & 1.4 & 3.8 \\
\hline
\end{tabular}

$\mathrm{SD}=$ standard deviation; *high dose statin treatment: atorvastatinum 40 - $80 \mathrm{mg}$ /rosuvastatinum 20 - 40 mg; moderate intensity statin treatment: atorvastatinum 10 - $20 \mathrm{mg} /$ rosuvastatinum 5 - 10mg/simvastatinum 20 - 40mg [17].

Statin treatment significantly increased the odds of patients' being at high risk for sarcopenia by a factor of $2.62(\mathrm{OR}=2.62,95 \% \mathrm{CI}$ : $1.53-4.46$; $\mathrm{p}<$ 0.001). Simvastatinum and atorvastatinum treatment was significantly associated with sarcopenia risk as opposed to rosuvastatinum and the likelihood of sarcopenia risk increased with statin dose (Table III). The association between the socio-economic factors and the high risk of sarcopenia was statistically significant for low income, low levels of formal education and living alone variables (Table III). 
Table III

Association between predictors and sarcopenia risk

\begin{tabular}{|c|c|c|c|c|}
\hline Predictor & B & SE & OR $(95 \% \mathrm{CI})$ & $\mathrm{p}$ value \\
\hline Statin use & 0.96 & 0.27 & $2.62(1.53-4.46)$ & $<0.001$ \\
\hline Statin type* & - & - & - & 0.001 \\
\hline rosuvastatinum & 0.22 & 0.52 & $1.24(.44-3.48)$ & 0.67 \\
\hline atorvastatinum & 1.05 & 0.4 & $2.86(1.28-6.36)$ & 0.01 \\
\hline simvastatinum & 1.13 & 0.31 & $3.09(1.66-5.75)$ & $<0.001$ \\
\hline Statin dose & 0.12 & 0.01 & $1.13(1.09-1.17)$ & $<0.001$ \\
\hline Rural residence & 0.11 & 0.16 & $1.11(0.8-1.54)$ & 0.5 \\
\hline Living alone & 1.08 & 0.18 & $2.95(2.06-4.21)$ & $<0.001$ \\
\hline Education** & - & - & - & $<0.001$ \\
\hline 4-8 years of formal education ${ }^{a}$ & 1.92 & 0.42 & $6.85(2.96-15.82)$ & $<0.001$ \\
\hline 9-12 years of formal education ${ }^{\mathrm{a}}$ & 1.51 & 0.34 & $4.54(2.33-8.85)$ & $<0.001$ \\
\hline Low income $e^{* * *}$ & 0.9 & 0.31 & $2.47(1.33-4.57)$ & 0.004 \\
\hline
\end{tabular}

$\mathrm{B}=$ regression coefficient; $\mathrm{SE}=$ standard error; ${ }^{*}$ with 3 degrees of freedom $(\mathrm{df}) ; * *$ with $2 \mathrm{df} ;{ }^{a}$ reference category $=$ university $/>12$ years of formal education; *** low income $=$ under the medium pension/month expressed in local currency RON: in 2015 was 892 RON, in 2016, 948 RON [35]; values in bold are statistically significant $(\mathrm{p}<0.05)$

When controlling for all other features, statin administration remained significantly associated with a high risk for sarcopenia (Table IV). Moreover, when tested for independency, the factors: living alone, low income, low levels of education and simvastatinum and atorvastatinum administration increased the odds of high risk of sarcopenia were greater. In contrast, persons living in urban areas were 4.76 times more likely to have a high risk for sarcopenia (Table IV).

Table IV

Logistic regression model for factors' associations with sarcopenia risk

\begin{tabular}{|c|c|c|c|c|c|}
\hline Factors & $\mathrm{B}$ & SE & Odds Ratio & $95 \% \mathrm{CI}$ for OR & $\mathrm{p}$ value \\
\hline Statin type* & - & - & - & - & $<0.001$ \\
\hline atorvastatinum & 1.26 & 0.38 & 3.54 & $1.67-7.48$ & 0.001 \\
\hline rosuvastatinum & -0.09 & 0.63 & 0.91 & $0.26-3.19$ & 0.88 \\
\hline simvastatinum & 1.71 & 0.51 & 5.54 & $2.03-15.06$ & 0.001 \\
\hline Rural residence & -1.52 & 0.62 & 0.21 & $0.06-0.74$ & 0.01 \\
\hline Living alone & 2.2 & 0.43 & 9.09 & $3.88-21.28$ & $<0.001$ \\
\hline Education** & - & - & - & - & 0.003 \\
\hline $4-8$ years of formal education ${ }^{a}$ & 2.08 & 0.66 & 8.06 & $2.17-29.82$ & 0.002 \\
\hline $10-12$ years of formal education ${ }^{\mathrm{a}}$ & 1.14 & 0.39 & 3.13 & $1.44-6.79$ & 0.004 \\
\hline Low income ${ }^{* * *}$ & 1.11 & 0.49 & 3.04 & $1.16-7.95$ & 0.02 \\
\hline
\end{tabular}

$\mathrm{B}=$ regression coefficient; $\mathrm{SE}=$ standard error; $*$ with $3 \mathrm{df} ; * *$ with $2 \mathrm{df} ;{ }^{a}$ reference category $=$ university $/>12$ years of formal education; *** low income $=$ under the medium pension/month expressed in local currency RON: in 2015 was 892 RON, in 2016, 948 RON [35]; values in bold are statistically significant $(\mathrm{p}<0.05)$; all predictors were entered in the model in a single step.

We designed several logistic regression models to evaluate the interaction between factors when tested for association with high risk for sarcopenia (data not shown). Because we found collinearity between income, residence and education level (95.83\% of people with low income were also living in rural areas and had low levels of education) we used a stepwise logistic regression analysis to identify the model that best fits the data. The chi square test of independence of the stepwise regression showed that living alone, statin use and low levels of formal education were features significantly associated with a high risk for sarcopenia $\left(\chi^{2}=45.05, \mathrm{p}<0.001 ; \chi^{2}=12.83, \mathrm{p}<\right.$ 0.001 respectively $\chi^{2}=15.74, \mathrm{p}<0.001$ ). In our sample, statin administration increased the likelihood of being at risk for sarcopenia by a factor of $3.21(\mathrm{OR}=3.21 ; 95 \% \mathrm{CI}=1.7-6.06 ; \mathrm{p}<0.001)$, living alone by a factor of $7.83(\mathrm{OR}=7.83 ; 95 \% \mathrm{CI}$
$=3.47-17.65 ; \mathrm{p}<0.001)$ and 4 to 8 years of formal education by a factor of $5.72(\mathrm{OR}=5.72$; $95 \% \mathrm{CI}=2.25-14.55 ; \mathrm{p}<0.001)$.

In our sample, almost half of the patients have been taking statins continuously for more than one year, mostly atorvastatinum and simvastatinum. Statin administration was independently associated with a high risk for sarcopenia. This effect was detected only for lipophilic statins, as opposed to rosuvastatinum which seemed to have a positive influence on gait speed even though not statistically significant. This observation might be explained by a superior penetration into muscle cells of the lipophilic drugs resulting in higher toxic effects $[36,37]$. Similar findings on the protective effects of hydrophilic but not lipophilic statins were described by an interventional study on factors associated with an increase in lean body mass after resisting training exercises [38]. 
Predictors model that best fits the data

\begin{tabular}{|c|c|c|c|c|c|}
\hline Factors & $\mathrm{B}$ & SE & Odds Ratio & $95 \% \mathrm{CI}$ for OR & $\mathrm{p}$ value \\
\hline Statin use & 1.16 & 0.32 & 3.21 & $1.7-6.06$ & $<0.001$ \\
\hline Living alone & 2.05 & 0.41 & 7.83 & $3.47-17.65$ & $<0.001$ \\
\hline Education* & - & - & - & - & 0.001 \\
\hline $4-8$ years of formal education ${ }^{\mathrm{a}}$ & 1.74 & 0.47 & 5.72 & $2.25-14.55$ & $<0.001$ \\
\hline $10-12$ years of formal education ${ }^{a}$ & 1.14 & 0.37 & 3.13 & $1.51-6.52$ & $<0.001$ \\
\hline
\end{tabular}

$\mathrm{B}=$ regression coefficient; $\mathrm{SE}=$ standard error; ${ }^{*}$ with $2 \mathrm{df} ;{ }^{\text {a }}$ reference category $=$ university $/>12$ years of formal education; values in bold are statistically significant $(\mathrm{p}<0.05)$; model was generated with a stepwise forward conditional method

However, simvastatinum and atorvastatinum are the drugs of choice in clinical trial based guidelines endorsements. Another prospective cohort study reported that statin use augments muscle performance decline and risk of falls in older age without a decrease in muscle mass [39]. In our group of study, patients at high risk for sarcopenia also had a high risk of falls. Persons living alone, in urban areas, with low income and lower levels of education were at high risk for sarcopenia. Nevertheless, these results might not be extrapolated to other populations as in our Romanian study sample we found that these factors were not independent of each other. The strongest predictors for high risk of sarcopenia, were statin use, low levels of education and living alone. We can speculate that these social factors have a negative impact on diet and physical activity levels thus increasing the risk of sarcopenia but future larger longitudinal studies are needed to establish how sociocultural and economic features influence muscle functioning in older age. Due to the small sample size, we could not evaluate the relationship between statin type and individual dosage with regard to sarcopenia risk.

\section{Conclusions}

Long term statin administration to older patients has to be carefully considered and managed given the likely increase in sarcopenia risk. Therapeutic decision should be individualized and based on patient's cardiovascular risk as well as other circumstantial factors such as education level and living arrangements as these features could potentially play a role in patient's lifestyle determinants of muscle function.

\section{References}

1. Cruz-Jentoft AJ, Baeyens JP, Bauer JM, Boirie Y, Cederholm T, Landi F, Martin FC, Michel JP, Rolland Y, Schneider SM, Topinková E, Vandewoude M, Zamboni M, European Working Group on Sarcopenia in Older People, Sarcopenia: European consensus on definition and diagnosis: Report of the European Working Group on Sarcopenia in Older People. Age Ageing, 2010; 39(4): 412-23.
2. Santilli V, Bernetti A, Mangone M, Paoloni M, Clinical definition of sarcopenia. Clinical Cases in Mineral and Bone Metabolism, 2014; 11(3): 177-180.

3. Von Haehling S, Morley JE, Anker SD, An overview of sarcopenia: facts and numbers on prevalence and clinical impact. Journal of Cachexia, Sarcopenia and Muscle. 2010; 1(2): 129-133.

4. Dodds RM, Roberts HC, Cooper C, Sayer AA, The epidemiology of sarcopenia. $J$ Clin Densitom., 2015; 18(4): 461-466.

5. Roubenoff R, Sarcopenia: a major modifiable cause of frailty in the elderly. J Nutr Health Aging, 2000; 4(3): 140-142.

6. Clynes M, Edwards M, Buehring B, Dennison E, Binkley N, Cooper C, Definitions of sarcopenia: associations with previous falls and fracture in a population sample. Calcified tissue international, 2015; 97(5): 445-452.

7. Moreland JD, Richardson JA, Goldsmith CH, Clase $\mathrm{CM}$, Muscle weakness and falls in older adults: a systematic review and meta-analysis. $J$ Am Geriatr Soc., 2004; 52(7): 1121-1129.

8. Janssen I, Baumgartner RN, Ross R, Rosenberg IH, Roubenoff R, Skeletal muscle cutpoints associated with elevated physical disability risk in older men and women. Am J Epidemiol., 2004; 159(4): 413-421.

9. Newman AB, Kupelian V, Visser M, Simonsick EM, Goodpaster BH, Kritchevsky SB, Tylavsky FA, Rubin SM, Harris TB, Strength, but not muscle mass, is associated with mortality in the health, aging and body composition study cohort. $J$ Gerontol A Biol Sci Med Sci., 2006; 61(1): 72-77.

10. Landi F, Russo A, Liperoti R, Pahor M, Tosato M, Capoluongo E, Bernabei R, Onder G, Midarm muscle circumference, physical performance and mortality: results from the aging and longevity study in the Sirente geographic area (ilSIRENTE study). Clin Nutr., 2010; 29(4):441-447.

11. Lang T, Streeper T, Cawthon P, Baldwin K, Taaffe DR, Harris TB, Sarcopenia: etiology, clinical consequences, intervention, and assessment. Osteoporos Int., 2010; 21(4): 543-59.

12. Rolland Y, Czerwinski S, Abellan Van Kan G, Morley JE, Cesari M, Onder G, Woo J, Baumgartner R, Pillard F, Boirie Y, Chumlea WM, Vellas B, Sarcopenia: Its assessment, etiology, pathogenesis, consequences and future perspectives. The journal of nutrition, health \& aging, 2008; 12(7): 433-450.

13. Cruz-Jentoft AJ, Landi F, Schneider SM, Zuniga C, Arai H, Boirie Y, Chen LK, Fielding RA, Martin FC, Michel JP, Sieber C, Stout JR, Studenski SA, Vellas B, Woo J, Zamboni M, Cederholm T, 
FARMACIA, 2018, Vol. 66, 4

Prevalence of and interventions for sarcopenia in ageing adults: a systematic review. Report of the International Sarcopenia Initiative (EWGSOP and IWGS). Age and Ageing, 2014; 43: 748-759.

14. Curtis E, Litwic A, Cooper C, Dennison E, Determinants of muscle and bone aging. Journal of cellular physiology, 2015; 230(11): 2618-2625.

15. Jie $\mathrm{Yu}$, The etiology and exercise implications of sarcopenia in the elderly. International Journal of Nursing Sciences, 2015; 2(2): 199-203.

16. Bales CW, Ritchie CS, Sarcopenia, weight loss, and nutritional frailty in the elderly. Аnпu Rev Nutr., 2002; 22: 309-323.

17. Stone NJ, Robinson JG, Lichtenstein AH, Bairey Merz CN, Blum CB, Eckel RH, Goldberg AC, Gordon D, Levy D, Lloyd-Jones DM, McBride P, Schwartz JS, Shero ST, Smith SC Jr, Watson K, Wilson PW; American College of Cardiology/ American Heart Association Task Force on Practice Guidelines, 2013 ACC/AHA guideline on the treatment of blood cholesterol to reduce atherosclerotic cardiovascular risk in adults: a report of the American College of Cardiology/American Heart Association Task Force on Practice Guidelines. $J$ Am Coll Cardiol., 2014; 63(25 Pt B): 2889-2934.

18. Catapano AC, Graham I, De Backer G, Wiklund O, Wiklund O, Chapman MJ, Drexel H, Hoes AW, Jennings CS, Landmesser U, Pedersen TR, Reiner Ž, Riccardi G, Taskinen MR, Tokgozoglu L, Verschuren WM, Vlachopoulos C, Wood DA, Zamorano JL, 2016 ESC/EAS Guidelines for the Management of Dyslipidaemias. Eur Heart J., 2016; 37(39): 2999-3058.

19. Parepa IR, Suceveanu AI, Mazilu L, Mohamed A, Niţă D, Tuţă LA, Preventing cardiac complications after non-cardiac non-vascular surgery by using perioperative statin therapy - A prospective study in Constanta County, Romania. Farmacia, 2017; 65(1): 120-124.

20. Tomaszewski M, Stępień KM, Tomaszewska J, Czuczwar SJ, Statin-induced myopathies. Pharmacol Rep., 2011; 63(4): 859-66.

21. Mohassel P, Mammen AL, The spectrum of statin myopathy. Curr Opin Rheumatol., 2013 ;25(6): 747-752.

22. Mammen AL, Statin-Associated Autoimmune Myopathy. N Engl J Med., 2016; 374(7): 664-669.

23. Wei MY, Ito MK, Cohen JD, Brinton EA, Jacobson TA, Predictors of statin adherence, switching, and discontinuation in the USAGE survey: understanding the use of statins in America and gaps in patient education. J Clin Lipidol., 2013; 7(5): 472-483.

24. Bruckert E, Hayem G, Dejager S, Yau C, Bégaud $\mathrm{B}$, Mild to moderate muscular symptoms with highdosage statin therapy in hyperlipidemic patients-the PRIMO study. Cardiovasc Drugs Ther., 2005; 19(6): 403-414.

25. Ilieşiu AM, Pârvu I, Hodorogea AS, Nanea IT, Popescu AC, Perspectives in lipid lowering therapy. New therapies targeting LDL - Cholesterol. Farmacia, 2018; 66(1): 8-17.

26. Antons KA, Williams CD, Baker SK, Phillips PS, Clinical perspectives of statin-induced rhabdomyolysis. Am J Med., 2006; 119(5): 400-409.
27. Tay L, Ding YY, Leung BP, Ismail NH, Yeo A, Yew S, Tay KS, Tan CH, Chong MS, Sex-specific differences in risk factors for sarcopenia amongst community-dwelling older adults. Age, 2015; 37(6): 1-12.

28. Cruz-Jentoft AJ, Baeyens JP, Bauer JM, Boirie Y, Cederholm T, Landi F, Martin FC, Michel JP, Rolland Y, Schneider SM, Topinková E, Vandewoude M, Zamboni M, European Working Group on Sarcopenia in Older People, Sarcopenia: European consensus on definition and diagnosis: Report of the European Working Group on Sarcopenia in Older People. Age and Ageing, 2010; 39(4): 412-423.

29. Peel NM, Kuys SS, Klein K, Gait speed as a measure in geriatric assessment in clinical settings: a systematic review. J Gerontol A Biol Sci Med Sci., 2013; 68(1): 39-46.

30. Abellan van Kan G, Rolland Y, Rolland Y, Andrieu S, Bauer J, Beauchet O, Bonnefoy M, Cesari M, Donini LM, Gillette Guyonnet S, Inzitari M, Nourhashemi F, Onder G, Ritz P, Salva A, Visser $\mathrm{M}$, Vellas B, Gait speed at usual pace as a predictor of adverse outcomes in community-dwelling older people an International Academy on Nutrition and Aging (IANA) Task Force. J Nutr Health Aging, 2009; 13(10): 881-889.

31. Lee J, Geller AI, Strasser DC, Analytical review: focus on fall screening assessments. PMR, 2013; 5(7): 609-621.

32. Hendrich AL, Bender PS, Nyhuis A, Validation of the Hendrich II Fall Risk Model: A Large Concurrent CASE/Control Study of Hospitalized Patients. Appl Nurs Res., 2003; 16(1): 9-21.

33. Hendrich A, Nyhuis A, Kippenbrock T, Soja ME, Hospital falls: development of a predictive model for clinical practice. Appl Nurs Res., 1995; 8(3): 129-139.

34. Breslow NE, Day NE, Statistical Methods in Cancer Research; Volume 1 - The Analysis of Case-Control Studies. Lyon, France: International Agency for Research on Cancer; 1980

35. National Institute of Statistics. Press Release No.72 March 2017. Number of pensioners and medium monthly pension in 2016. Available at: www.insse.ro.

36. Di Stasi SL, MacLeod TD, Winters JD, BinderMacleod SA, Effects of Statins on Skeletal Muscle: A Perspective for Physical Therapists. Physical Therapy, 2010; 90(10): 1530-1542.

37. Catapano AL, Statin-induced myotoxicity: pharmacokinetic differences among statins and the risk of rhabdomyolysis, with particular reference to pitavastatin. Curr Vasc Pharmacol., 2012; 10(2): 257-267.

38. Riechman SE, Andrews RD, Maclean DA, Sheather S, Statins and dietary and serum cholesterol are associated with increased lean mass following resistance training. J Gerontol A Biol Sci Med Sci., 2007; 62(10): 1164-1171.

39. Scott D, Blizzard L, Fell J, Jones G, Statin therapy, muscle function and falls risk in communitydwelling older adults. QJM, 2009; 102(9): 625-633. 